\title{
Strategi dan Fungsi Linguistik Kekuasaan dalam Naskah Babad Lombok
}

\author{
Lalu Habiburrahman ${ }^{1}$
}

\begin{abstract}
Abstrak
Periode lahirnya naskah babad di Jawa dan Bali sekitar abad ke18, tetapi lebih banyak ditulis sekitar abad ke-19. Pada masa-masa tersebut, Lombok berada di bawah kekuasaan Bali. Kekuasaan Bali di Lombok bahkan telah terjadi sejak abad sebelumnya, yakni akhir abad ke-17 dan bertahan hingga akhir abad ke-19. Tradisi babad berkembang juga di Lombok. Salah satu di antaranya adalah Naskah Babad Lombok. Di antara Naskah Babad Lombok, salah satunya sudah ditransliterasi dan diterjemahkan ke dalam Bahasa Indonesia oleh Lalu Gde Suparman. Naskah hasil transliterasi dan terjemahan ini akan menjadi objek dalam penelitian ini. Penelitian ini menggunakan pendekatan wacana sejarah. Penelitian ini menghasilkan strategi dan fungsi linguistik kekuasaan dalam naskah Babad sebagai berikut. Pertama, dengan membangun garis generasi elit Lombok dengan Nabi Nuh. Kedua, dengan pencitraan negatif garis generasi terakhir penguasa Pejanggik dan Selaparang. Ketiga, munculnya Mitos Arya Banjar Getas sebagai pemegang "wahyu kekuasaan" terakhir di Lombok dari Generasi Majapahit. Fungsi kekuasaan di dalam Naskah Babad Lombok sebagai berikut. Pertama, untuk membangun legitimasi kekuasaan dengan simbol raja sebagai pusat kekuasaan dan kosmos. Kedua, sebagai dasar legitimasi sosial politik atas pemberontakan dan penggulingan kekuasaan yang dilakukan oleh Arya Banjar Getas terhadap Raja Pejanggik dan Selaparang; berikutnya adalah usaha elit Lombok untuk menjaga status sosial yang telah menempatkan mereka pada kedudukan politik yang lebih tinggi dari masyarakat pada umumnya. Ketiga, sebagai wacana perlawanan untuk menempatkan elit Politik Lombok dan Bali sejajar secara politik; berikutnya adalah sebagai bentuk perlawanan untuk menunjukkan tingkat status sosial mereka sebagai kelompok arya.
\end{abstract}

Kata kunci: strategi, fungsi, wacana pendekatan sejarah, Babad Lombok

\footnotetext{
${ }^{1}$ Penulis adalah pengajar pada IKIP Mataram
} 
36| Mabasan - Vol. 5, No. 2, Juli-Desember 2011

\section{Pendahuluan}

\subsection{Latar Belakang}

Wacana, kekuasaan, dan sastra adalah tiga dimensi yang berbeda. Wacana secara etimologis diartikan sebagai satuan bahasa terlengkap, satuan gramatikal tertinggi dan terbesar. Wacana dalam tradisi Barat berasal dari vacana (Sansekerta), berarti kata-kata, cara berkata, ucapan, pembicaraan, perintah dan nasihat. Dalam Bahasa Inggris, wacana disebut discourse. Discourse berasal dari kata discurrere (Latin) yang berarti gerak maju mundur (dari dan ke). Selain kata wacana, tradisi kesusastraan Barat mengenal pula istilah teks. Teks berasal dari kata textum (Latin), yang berarti tenunan, jalinan, dan susunan. Istilah wacana atau diskursus lebih sering digunakan dalam kehidupan praktis sehari-hari, terutama dalam ilmu bahasa dan dalam ilmu social, sedangkan istilah teks umumnya digunakan dalam sastra. Dalam perkembangan teori sastra kontemporer, kedua istilah tersebut seolah-olah hadir secara bersaing. Wacana menjadi konsep kunci dalam teori postmodernisme dan postrukturalisme. Bahkan, diduga dalam perkembangan berikutnya, istilah wacana akan mendominasi bukan saja dalam pengertian umum, tetapi juga sastra (periksa Ratna, 2009:243-245).

Menurut Fowler (1985:61), kekuasaan adalah kemampuan yang dimiliki seseorang, lembaga, atau instansi dalam mengontrol perilaku dan kehidupan material orang lain. Kekuasaan adalah persoalan hubungan timbalbalik antara "penguasa" dan "terkuasai". Sementara itu, Fairclough (1995:1) yang memandang dari sudut pandang konseptual menyebutkan bahwa kekuasaan memiliki dua makna, yaitu (1) ketidaksimetrisan antarpartisipan dalam peristiwa-peristiwa wacana (discourse events); dan (2) ketidaksamaan kapasitas dalam mengontrol bagaimana sebuah teks diproduksi, didistribusikan, dan dikonsumsi dalam konteks-konteks sosial budaya tertentu (Santoso, 2001:44). Sastra secara etimologis dapat diartikan sebagai seni hidup dalam dunia imajinasi yang disajikan melalui sebuah media, yakni bahasa (Kuntowijoyo, 2004:17, bandingkan dengan Santoso, 2000:251).

Wacana, kekuasaan, dan sastra bisa menjadi satu dalam karya sastra. Damono (1981:1) menjelaskan bahwa selain merupakan seni hidup berupa eksperimen moral yang dituangkan melalui bahasa, sastra dalam kenyataannya menampilkan gambaran kehidupan; dan kehidupan itu sendiri merupakan kenyataan sosial (dalam Santoso 2000:251). Dengan kata lain, wacana terwakilkan oleh susunan kata, frasa, kalimat, paragraf, dan seterusnya; 
kekuasaan terwakilkan oleh gambaran kehidupan/kenyataan sosial hasil olah rasa dan batin pengarang; dan sastra sebagai bentuk yang dipilih pengarang dalam mewujudkan seni kehidupan hasil eksperimen batinnya, bukan menyusunnya sebagai dokumen sejarah dan lain-lain.

Permasalahan wacana kekuasaan di dalam karya sastra bukanlah hal yang baru. Epos lama Ramayana dan Mahabarata karya Walmiki dan Wyasa, tak luput juga mempermasalahkan kekuasaan negara di antara para pelakunya (Santoso, 2000:251). Dalam tradisi kesusastraan Klasik di Indonesia, permasalahan tersebut juga dapat dijumpai. Wacana kekuasaan dalam kesusastraan klasik Indonesia muncul dalam bentuk mitos-mitos politik yang magis. Hal ini menyebabkan teks tidak lagi berfungsi sekuler, yakni untuk mencatat sejarah melainkan cenderung untuk memberikan legitimasi atas hegemoni politik penguasa tertentu. Akan tetapi, yang unik ternyata hanya kerajaan-kerajaan besar, seperti Melayu dan Mataram dengan tradisi sastra tulis yang menciptakan mitos-mitos seperti itu. Adapun dalam masyarakat kesukuan, mitos, sejarah, dan sastra tidak bersifat sakral, tetapi profan semata. Dalam masyarakat kesukuan, ketiganya hanyalah rekfleksi kultural, hiburan, dan sejarah (periksa Kuntowijoyo, 2004:18).

Oleh karena itu, tidak mengherankan ketika s-Gravenhage (1941) dan Errington (mengutip Malinowski 1972:26-42) mengatakan bahwa dalam Babad Tanah Jawi dan Hikayat Hang Tuah dapat dijumpai kekuasaan dalam bentuk mitos. Munculnya mitos tersebut bertujuan sebagai alat pembenaran tertib sosial. Meskipun didasarkan pada kejadian yang sebenarnya, pengarang mitos (yang selalu anonim) mempunyai maksud politik, yaitu usaha memperkuat kedudukan sang patron. Fungsi teks tidak sekuler, yaitu untuk mencatat sejarah, tetapi mempunyai fungsi magis (Kuntowijoyo, 2004:18).

Tradisi babad tidak hanya berkembang di Jawa, tetapi menyebar ke Bali hingga ke Lombok. Mengenai periode penulisan naskah babad, merujuk pada hasil penelitiannya di Bali, Hagerdal (1998:154) menyebutkan bahwa penulisan naskah babad-babad di Bali tidak akan lebih awal dari abad ke-18, bahkan kebanyakan dari naskah-naskah babad tersebut kemungkinan ditulis abad ke-19 dan abad ke-20. Penelitian lain terhadap naskah serupa pernah dilakukan Ricklefs terhadap beberapa naskah di Jawa, antara lain Naskah Babad Jawa dan Sejarah Banten. Dari penelitian tersebut, Ricklefs menemukan bahwa naskah asli Babad Tanah Jawi ditulis pada tahun 1730-an dan 1740-an. Sejarah Banten 
yang berisi cerita-cerita pengislaman, sebagian besar bertarikh akhir abad ke-19 (Ricklefs, 2009:17-19).

Pada periode lahirnya naskah babad di Jawa dan di Bali tersebut, Lombok sedang berada di bawah kekuasaan Bali Gelgel yang dilanjutkan oleh Bali Karangasem. Kekuatan politik Bali bahkan telah menguasai Lombok sejak abad ke-17 dan menjadi dominan sejak sekitar pertengahan abad ke-18 hingga akhir abad ke-19. Dengan demikian, patut dicurigai bahwa di dalam Naskah Babad Lombok terkandung wacana kekuasaan yang tentunya dituangkan dengan strategi tertentu untuk fungsi-fungsi yang berkaitan dengan kepentingan elit Lokal (Lombok) dan penguasa Bali (Gelgel dan Karangasem).

Artikel ini bermaksud membicarakan tentang strategi dan fungsi kekuasaan pada salah satu tradisi babad di Lombok, yakni Naskah Babad Lombok dengan terlebih dahulu melihat konteks politik di Lombok pada sekitar periode lahirnya tradisi babad. Objek penelitian akan difokuskan pada Naskah Babad Lombok hasil translterasi dan terjemahan oleh Lalu Gde Suparman yang telah diterbitkan dalam bentuk buku berjudul Babad Lombok oleh Pusat Pembinaan dan Pengembangan Bahasa Depdiknas pada tahun 1994.

\subsection{Metode}

Penelitian ini menggunakan pendekatan wacana sejarah yang dikembangkan oleh Wodak. Dalam pendekatan wacana sejarah, analisis wacana harus menyertakan konteks sejarah bagaimana wacana tentang suatu kelompok atau komunitas digambarkan, misalnya dalam penggambaran yang buruk atau rasis tentang suatu kelompok. Dalam sudut pandang pendekatan ini, wacana nantinya dianggap terbangun lewat proses sejarah yang panjang. Prasangka, bias, misrepresentasi, dan sebagainya selanjutnya harus dibongkar dengan melakukan tinjauan sejarah (Eriyanto, 2009:17-18).

Dalam pelaksanaan penelitian, prosedur wacana sejarah yang dikembangkan Wodak dipandang bersifat hermeneutika dan interpretatif yang mendapat sedikit pengaruh dari ilmu kognitif. Dengan demikian, prosedur penelitiannya merupakan rangkaian langkah operasional yang terpisah, namun sebagai siklus yang saling terkait, tempat terkaitnya secara sistematis dan rekursif tiga dimensi analitis dengan totalitas pengetahuan kontekstual (Titscher, dkk. 2009:260). 


\section{Pembahasana}

\subsection{Kondisi Politik di Lombok Antara Abad Ke-17 Hingga Abad Ke-19}

Sebagaimana telah disinggung sebelumnya, pada sekitar periode lahirnya naskah babad, yakni antara abad ke-18 hingga abad ke-19, politik di Lombok berada di bawah pengaruh Bali. Kekuasaan itu sendiri telah berlangsung sejak awal abad ke-17. Dalam catatan kaki oleh Pangarsa (1992:91, dalam Hagerdal 1998:71) disebutkan "briefly mentions a local text from 1631 describing a Balinese aristocrat who was in power in village of Karanglangu in North Lombok”. Karanglangu yang disebutkan di dalam salah satu naskah lokal Bali tersebut, saat ini terletak beberapa ratus meter dari pusat Kota Tanjung, Lombok Utara.

Hagerdal (1998:73-74) menguraikan sebagai berikut. Di antara sejumlah petinggi penting Raja Bali, salah satu di antaranya adalah Gusti Agung. Ia muncul sebagai tokoh politik yang cukup penting dalam sejarah kekuasaan di Bali. Setelah penyerangan yang pernah dilakukan sebelumnya, pada tahun 1645, ia berangkat menemui kedatuan di Sasak (Lombok). Ia berhasil menguasai sejumlah tempat penting di Lombok, kemungkinan berlawanan arah jarum jam dari timur ke utara. Hal ini dilakukan sebagai usaha membangun aliansi dengan kelompok-kelompok penduduk muslim. Dengan cara yang sangat hati-hati ia melakukan pendekatan terhadap setiap penguasa kelompok-kelompok tersebut.

Berdasarkan catatan kronogram dalam dua naskah di Bali, yakni Babad Tusan yang tergabung dalam bundel berjudul ungkahing Sundari-Terus (Leiden University Library, LOr 13.192) dan Pawawatekan, Hagerdal (1998:72 - 73) mencatat beberapa hal sebagai berikut. Catatan kronogram dari Babad Tusan merujuk pada angka tahun saka 1567 atau 1645 M., ketika Bali berhasil menaklukkan beberapa daerah di Lombok yang meliputi Selaparang, Parigi, Samalyan, dan Bayan. Catatan kronogram Babad Tusan juga menjelaskan masa ketika Gusti Agung berada di Padang, yakni pada purnama Ca., Wa., Minggu Dukut, bulan ketiga penanggalan saka (antara AgustusSeptember) tahun 1567 atau 1645 M., ketika Gusti Agung mengirim pesan ke Batuparang.

Catatan Kronogram yang diungkap Hagerdal yang bersumber dari Pawawataken menyebutkan tentang kembalinya Raden Sabit ke daerah bernama Langkong pada sekitar Mei-Juni tahun 1567 saka atau $1645 \mathrm{M}$. 
40| Mabasan - Vol. 5, No. 2, Juli-Desember 2011

Langkong atau Langko adalah kerajaan yang saat ini letaknya diperkirakan berada di sebelah tenggara dari pusat Kota Praya, Lombok Tengah.

Informasi lain diungkapkan oleh Cool (1897:173) yang menguraikan sebagai berikut. Merujuk pada laporan tahun 1679, Cool menjelaskan bahwa pada masa tersebut, untuk pertama kalinya Bali di Lombok terbebas dari pengaruh dominasi Makassar. Orang Bali tampaknya telah mengambil keuntungan dari kondisi politik yang kacau di Sumbawa untuk mengembangkan pengaruh mereka di Lombok dan berlanjut hingga ke Sumbawa. Usaha serius Bali dalam rangka mengambil alih Lombok ke dalam kekuasaannya terjadi tahun 1692. Kraan (2009:5-6) merinci periode penguasaan di Lombok dalam tiga tahapan sebagai berikut.

Tahap pertama yakni antara 1678 - 1740, pada tahapan ini, Bali terus mengembangkan wilayahnya hingga mencapai Sumbawa, tetapi mereka terpaksa kembali dan hanya memperkuat kekuasaannya di Lombok.

Tahap kedua adalah ketika masa kekuasaan Gusti Wayan Tegah, yakni 1740 — 1775. Pada masa ini, orang Bali tampaknya telah dapat mempertahankan kekuasaan mereka atas orang Sasak. Orang Bali disatupadukan, sehingga kecil kemungkinan timbulnya distrik-distrik Sasak yang merdeka. Dalam segi apapun, tidak ada tanda-tanda adanya penentangan yang berarti terhadap kekuasaan Bali.

Tahap ketiga antara tahun 1775-1838. Pada masa ini, Wayan Tegah telah meninggal, dan memuncul perselisihanperselisihan di kalangan dua orang pangeran penggantinya yang bersaing, mengakibatkan pada sekitar tahun 1800, kerajaan tersebut menjadi terpecah. Hingga pada permulaan abad ke-19, kerajaan yang ditinggalkan Wayan Tegah telah terpecah menjadi 4 wilayah, yakni Kerajaan utama Cakranegara (juga dinamakan Karangasem Lombok), Mataram, Pagesangan dan Pagutan.

Dari data yang ada terlihat, sejak paruh pertama hingga pertengahan abad ke-17, Bali sepertinya telah berhasil memengaruhi elit-elit lokal Lombok di daerah pesisir barat dan berlanjut ke daerah tengah dan utara. Pada pertengahan hingga akhir abad ke-17, mereka telah bergerak ke timur mendekati pusat kekuasaan Selaparang yang telah membangun aliansi dengan 
Sumbawa-Makassar. Periode akhir abad ke-17 hingga pertengahan abad ke-18, kekuasaan mereka telah mapan di Lombok.

Bagaimana Raja Sumbawa dan Raja Makassar bereaksi terhadap perluasan pengaruh Bali di Lombok? Tentang hal ini tidak ada penjelasan lebih jauh. Naskah-naskah di Bali memang berbicara tentang perang Bali dengan Jawa dan Lombok, tetapi tidak dengan Makassar. Informasi mengenai hal ini didapatkan dari kronik Makassar yang menyatakan bahwa masyarakat Selaparang bukanlah jajahan dari penguasa Makassar, tetapi mereka mencari perlindungan akan kebebasan di wilayahnya, barangkali untuk urusan penataan wilayahnya yang luas (Hagerdal, 1998:74).

Berdasarkan informasi lebih lengkap yang tersedia dari data tahun 1670, Hagerdal (1998:75) menjelaskan sebagai berikut. Lombok atau setidaknya bagian timur Pulau Lombok berada di bawah dominasi Sumbawa sehingga mengakibatkan pengaruh Bali di Lombok menjadi berkurang selama periode perang internal pada tahun 1650-an. Pertanyaan selanjutnya adalah konsekuensi yang ditimbulkan oleh adanya perebutan pengaruh tersebut. Lombok pada waktu itu memegang peranan penting bagi perekonomian di Bali atau garis elit di Bali. Hal ini didasarkan pada laporan Belanda dari awal tahun 1600-an. Laporan tersebut menyebutkan bahwa beras dalam jumlah yang besar dikirim ke Bali setiap hari melalui Selat Lombok. Selain itu, orang-orang Jawa sering datang ke pulau tersebut untuk membeli beras, budak perempuan, dan kain tenun. Sebuah surat Belanda dari tahun 1656 juga menekankan fakta bahwa sejumlah beras dapat diperoleh di Belambangan dan Lombok.

Jika kita memperhatikan kronologi peristiwa-peristiwa di atas, ada beberapa hal yang bisa catat. Pertama, hingga pertengahan abad ke-17, Bali sepertinya telah menguasai Lombok Barat, Lombok Tengah, dan Lombok Utara. Untuk mengetahui lebih mendalam tentang batas-batas kewenangan Bali atas daerah kekuasaannya, tentunya diperlukan penelitian lanjutan. Namun, dari data-data yang ada, setidaknya tergambar bahwa pada kurun waktu tersebut, Bali telah berhasil mengendalikan kepentingan kelompok-kelompok elit Lombok, bahkan mengarahkan mereka untuk mengambil peran langsung dalam usaha menyingkirkan pengaruh Sumbawa-Makassar atas Selaparang. Kedua, secara politik, elit-elit Bali telah memainkan peran yang sangat cerdas dalam menyatukan faksi-faksi elit Lombok yang terpecah sehingga mampu menjadikan diri sebagai kekuatan sentral yang mengakomodir faksi-faksi tersebut. Ketiga, Selaparang sebagai kekuatan terbesar di Lombok sepertinya 
hanya mengonsentrasikan kekuatan-kekuatan mereka di pesisir timur. Wilayah tengah, utara, dan pesisir barat dibiarkan terserak menjadi kekuatan-kekuatan kecil.

\subsection{Strategi dan Fungsi Linguistik Kekuasaan dalam Naskah Babad Lombok}

Strategi linguistik kekuasaan dalam Babad Lombok muncul melalui beberapa strategi sebagai berikut. Pertama, membangun garis generasi elit Lombok dengan Nabi Nuh. Fungsi kekuasaan dari strategi ini, yakni sebagai alat legitimasi sosial politik elit Lombok. Secara ringkas, generasi raja-raja Lombok yang diungkap di dalam Babad Lombok sebagai berikut. Raja Lombok yang pertama diangkat menjadi raja di Pamatan diceritakan sebagai keturunan dari Nabi Nuh. Raja yang berkuasa di Bayan diceritakan sebagai generasi dari Raja Pamatan. Raja Lombok setelah di Selaparang, yakni Prabu Mraja Anom juga diceritakan sebagai generasi dari Raja Bayan yang berasal dari keturunan Raja Pamatan, dari generasi Nabi Nuh. Arya Banjar Getas yang kemudian menggulingkan Raja Pejanggik diceritakan sebagai arya, yakni gelar yang disandang orang-orang terdekat Majapahit. Antara Majapahit, Pamatan, dan Pejanggik di dalam Babad Lombok diceritakan memiliki hubungan kekerabatan.

Munculnya wacana kekuasaan dengan membangun garis generasi kepada Nabi Nuh sangat berkaitan dengan ideologi yang berkembang di Lombok sejak abad ke-15 yang dikembangkan oleh Sunan Giri, yakni Islam sufistik. Dengan adanya wacana raja-raja Lombok sebagai keturunan nabi, dalam konteks sosial, hal ini akan menjadikan raja sebagai pusat kekuasaan dan daya magis.

Kedua, melalui pencitraan negatif raja terakhir Pejanggik dan Selaparang di dalam Babad Lombok. Fungsi-fungsi linguistik kekuasaan dengan pencitraan negatif penguasa terakhir Pejanggik dan Selaparang ini sebagai berikut. Pencitraan negatif raja terakhir Pejanggik berfungsi sebagai pembenaran. Di dalam Babad Lombok diceritakan sebagai berikut. Suatu ketika, terjadi pemberontakan di Selaparang. Pelaku pemberontakan di Selaparang adalah Arya Banjar Getas. Setelah gagal dalam usahanya di Selaparang, ia kemudian melarikan diri ke Pejanggik. Di Pejanggik ia dilindungi, bahkan diberikan jabatan tinggi yakni sebagai patih mangkubumi. Ketika menduduki jabatan tersebut, ia kemudian memberontak terhadap Pejanggik. Dengan dukungan kekuatan dari Raja Karangasem beserta elit-elit 
Lombok pesisir barat, ia berhasil menggulingkan kekuasaan Raja Pejanggik. Ia kemudian membangun kekuasaannya di Praya. Sementara itu, Raja Karangasem terus melanjutkan penaklukannya hingga berhasil menghancurkan Selaparang. Dengan demikian, fungsi linguistik pencitraan negatif terhadap Pejanggik di dalam Babad Lombok dimaksudkan untuk membenarkan tindakan pemberontakan yang dilakukan oleh Arya Banjar Getas; membenarkan perlindungan Raja Pejanggik terhadapnya ketika menjadi buruan Selaparang; dan sekaligus membenarkan penaklukan-penaklukan lebih lanjut di Lombok yang dilakukan oleh Karangasem.

Berikutnya, fungsi dari strategi kekuasaan dengan pencitraan negatif Raja Selaparang, yakni sebagai penolakan elit Lombok terhadap garis generasi dari Sumbawa. Dalam Babad Lombok, raja terakhir Selaparang diceritakan sebagai keturunan dari Raja Seran, Horan, Sumbawa. Ia diceritakan sebagai raja yang menjadi pelindung perampok dan perompak. Dalam catatan historis, Lombok pada periode pertengahan abad ke-17 pernah menjalin hubungan politik dengan kekuatan Sumbawa, Makassar, dan Bali. Hubungan politik Lombok dengan Sumbawa-Makassar terjadi melalui perkawinan antara putra Raja Selaparang, Mas Pamayang, dengan adik tiri Karaeng Matoaya, yakni Karaeng Panaikang Daeng Niaq yang terjadi pada hari Sabtu tanggal 24 Desember 1650 (Noorduyn, 1987:312-313). Perkawinan politik ini tidak muncul di dalam Babad Lombok yang seharusnya sebagai dasar legalitas pemangku "wahyu kekuasaan" bagi raja-raja Selaparang, mengingat dalam kurun waktu abad ke-17 hingga paruh kedua pertengahan abad tersebut, Makassar merupakan kekuatan terbesar di wilayah Nusantara bagian timur.

Hubungan politik Lombok dengan Bali (Gelgel dan Karangasem) pada waktu itu (sekitar abad ke-17) lebih pada peran Bali sebagai kekuatan yang mampu memobilisasi kelompok kedatuan-kedatuan yang ada di Lombok. Dalam Babad Lombok, diuraikan bahwa daerah-daerah pesisir barat, tengah, utara hingga timur memilih bergabung dengan kekuatan Bali (Gusti Ngurah) di bawah pimpinan senapati dan empat perbekel yang bergabung dengan kekuatan lokal di bawah pimpinan Arya Banjar Getas (Babad Lombok, bait 1121-1203). Hal ini tentu berbeda dengan perkawinan antara Mas Pamayang dan Daeng Niak yang justru tidak sedikit pun diungkap di dalam Babad Lombok. Padahal secara historis, peristiwa itu pernah terjadi, sama dengan persebaran pengaruh Penguasa Bali di Pulau Lombok. 
Gambaran citra yang muncul tentang generasi dari Sumbawa justru negatif, yakni dengan menggambarkan raja sebagai pelindung perampok dan perompak. Munculnya wacana tersebut dalam Babad Lombok dimungkinkan sebagai bentuk penolakan elit Lombok terhadap generasi elit Sumbawa. Jika elit Lombok mengakui generasi dari Sumbawa, sama artinya dengan menempatkan mereka dalam posisi menentang kekuasaan tertinggi di Lombok pada periode tersebut, terutama mengingat kegagalan Bali dalam melakukan ekspansi ke Sumbawa. Dengan demikian, pencitraan negatif penguasa dari generasi Sumbawa dalam Babad Lombok berfungsi sebagai bentuk penerimaan elit Lombok berada di bawah dominasi Bali.

Ketiga, Arya Banjar Getas sebagai Pengemban Baru "wahyu kekuasaan" di Lombok dalam Babad Lombok. Fungsi wacana ini dalam Babad Lombok adalah untuk perjuangan kelas sosial elit Lombok. Dari penelusuran nama Arya Banjar Getas secara etimologis, didapati beberapa hal sebagai berikut. Gabungan banjar dan getas bisa diartikan sebagai dukuh atau kampung yang rapuh dan terpecah-pecah. Arya di depan nama Banjar Getas tidaklah umum dalam tradisi di Lombok. Gelar arya justru merupakan gelar tinggi semasa Majapahit yang disandang oleh kerabat dekat istana ${ }^{2}$.

Perlawanan kelas melalui gelar arya ini dapat dipahami melalui dua hal. Pertama, secara politik, elit Lombok pada masa kekuasaan Bali menduduki kelas sosial yang rendah, yakni perwangsa yang berkedudukan di bawah triwangsa (brahmana, ksatria dan weisya). Dengan demikian, munculnya gelar arya yang disandang oleh Banjar Getas akan menempatkan mereka setara dengan kelas triwangsa. Hal itu mengingat mereka adalah keturunan dari Majapahit. Semasa Majapahit, gelar arya adalah gelar tinggi yang disandang oleh kalangan kerabat kerajaan.

\section{Penutup}

Dari pembahasan yang telah dilakukan, dapat ditarik beberapa simpulan sebagai berikut. Pertama, kondisi politik Lombok secara internal sangat kacau. Di Lombok Barat, Lombok Tengah, dan Lombok Utara, elit-elit tersegmentasi dalam kedatuan-kedatuan kecil (kelompok kecil di bawah datu/raja) yang terus berlangsung hinga akhir abad ke-19. Kondisi ini kemudian dimanfaatkan oleh kekuatan Bali untuk diadu dengan otoritas terbesar yang ada di Lombok saat itu, yakni Selaparang.

\footnotetext{
${ }^{2}$ Lebih jauh mengenai gelar arya, periksa Mulyana (2009: 185-187)
} 
Kedua, Strategi dan fungsi linguistik kekuasaan dalam Naskah Babad Lombok sebagai berikut. Pertama, membangun garis generasi elit Lombok dengan Nabi Nuh berfungsi sebagai legitimasi kekuasaan elit politik di Lombok. Kedua, pencitraan negatif garis generasi terakhir penguasa Pejanggik berfungsi sebagai pembenaran atas penggulingan kekuasaan yang dilakukan Banjar Getas terhadap penguasa Pejanggik yang dibantu oleh Karangasem dan sekaligus sebagai pembenaran atas penggulingan kekuasaan-kekuasaan tertinggi di Lombok oleh Karangasem. Fungsi pencitraan negatif raja terakhir Selaparang adalah sebagai bentuk penerimaan elit Lombok untuk berada di bawah dominasi Bali. Ketiga, mitos Arya Banjar Getas sebagai pemegang "wahyu kekuasaan" di Lombok berfungsi sebagai bentuk perjuangan kelas sosial perwangsa agar dianggap setara dengan kelas sosial triwangsa. Hal itu mengingat gelar arya yang disandang Banjar Getas merupakan gelar tinggi semasa Majapahit dan dijabat oleh kalangan keluarga keraton. Gelgel dan Karangasem menganggap diri penerus dari tradisi Majapahit.

\section{DAFTAR RUJUKAN}

Cool, W. 1897. With the Dutch in the East An Outline of the Military Operations in Lombok, 1894. London: Luzae \&Co., Publishers to the India Office, 45, Greet Russell Street

Darma, Aliah Yoce. 2009. Analisis Wacana Kritis. Bandung: Yrama Widya

Djafar, Hasan. 2009. Masa Akhir Majapahit Girindrawadhana dan Masalahnya. Jakarta: Komunitas Bambu

Eriyanto. 2009. Analisis Wacana Pengantar Analisis Teks Media. Yogyakarta: PT. LKIS Printing Cemerlang

Fathurahman, Oman. 2000. Filologi dan Penelitian Teks-Teks Keagamaan. Makalah Disajikan pada Workshop Pengembangan Agenda Riset, Diselenggarakan oleh Local Project Implementing Unit (LPIU) Uin Syarif Hidayatullah Jakarta, Wisma YPI, Ciawi Bogor, 27 Maret 2000

Hagerdal, Hans. 1995. Bali in the Sixteenth and Seventeenth Centuries, Suggestions for Chronology of the Gelgel Period, dalam Bijdragen tot de Taal-, Land- en Volkenkunde, (Online), 151 (1): 101-124, (http://www.kitlv-journals.nl), diakses 10 November 2009. 
Hagerdal, Hans. 1998. From Batuparang to Ayudhya, Bali and Outside World, 1636-1656, dalam Bijdragen tot de Taal-, Land- en Volkenkunde, (Online), 154 (1): 55-94, (http://www.kitlv-journals.nl), diakses 10 November 2009

Kaelan, M.S. 2009. Filsafat Bahasa Semiotika dan Hermeneutika. Yogyakarta: Paradigma

Kuntowijoyo, 2004. Sejarah/Sastra, dalam Humaniora Volume 16, No. 1, Pebruari 2004:17-26

Marissons G.E. 2009. Penerjemahan di Lombok. dalam Loir, Chambert Henri (Peny.), Sadur Sejarah Terjemahan di Indonesia dan Malaysia (hlm. 285-298). Jakarta: PT. Gramedia

Muljana Slamet. 2009. Tafsir Sejarah Negara Kretagama. Yogyakarta. PT. LKIS Printing Cemerlang

Muljana Slamet. 2008. Runtuhnya Kerajaan Hindu-Jawa dan Timbulnya Negara-negara Islam di Nusantara. Yogyakarta: PT. LKIS Printing Media

Nurduyn, J. 1987. Islamisation of Bima. dalam Bijdragen tot de Taal-, Land- en Volkenkunde, (Online), 143 (2/3): 312-342, (http://www.kitlvjournals.nl), diakses 10 November 2009

Nugroho, Djoko Irawan. 2009. Meluruskan Sejarah Majapahit. Yogyakarta: Ragam Media

Rahardjo, Mudjia. 2007. Hermeneutika Gadamerian Kuasa Bahasa dalam Wacana Politik Gus Dur. Malang: UIN Pres

Ratna, Nyoman Kutha. 2009. Teori, Metode, dan Teknik Penelitian Sastra dari Strukturalisme hingga Poststrukturalisme Persfektif Wacana Naratif. Yogyakarta: Pustaka Pelajar

Ricklefs, M.C. 2008. A History of Modern Indonesia Since c. 1200 Fourth Edition. Terjemahan oleh Tim Penerjemah Serambi. Jakarta: PT. Serambi Ilmu Semesta

Santoso, 2000. Kekuasaan, Ideologi, dan Politik dalam Dunia Kesusastraan, Dalam Satoto, Soediro dan Fananie, Zainuddin (editor). Sastra: Ideologi, Politik, dan kekuasaan (hlm. 249-270), Surakarta: Muhammadiyah University Press 
Strategi dan Fungsi Linguistik Kekuasaan... (Lalu Habiburrahman) $\mid \mathbf{4 7}$

Suparman, Gede Lalu. 1994. Babad Lombok. Jakarta : Pusat Pembinaan dan Pengembangan Bahasa Departemen Pendidikan dan Kebudayaan

Tim Penyusun Kamus Pusat Bahasa. 2008. Kamus Bahasa Indonesia. Jakarta: Pusat Bahasa Departemen Pendidikan Nasional

Titscher, dkk. Tanpa tahun. Metode Analisis Teks dan Wacana. Terjemahan oleh Gazali dkk. 2009. Yogyakarta. Pustaka Pelajar

Van der Kraan, Alvons. Tanpa tahun. Lombok: Penaklukan, Penjajahan, dan Keterbelakangan 1870 - 1940. Terjemahan oleh M. Dony Supanra. 2009. Mataram. Lengge Printika 